\title{
Carlos F. Dumlao, MD (1950-2018)
}

\author{
Alfredo Q. Y. Pontejos Jr., MD
}

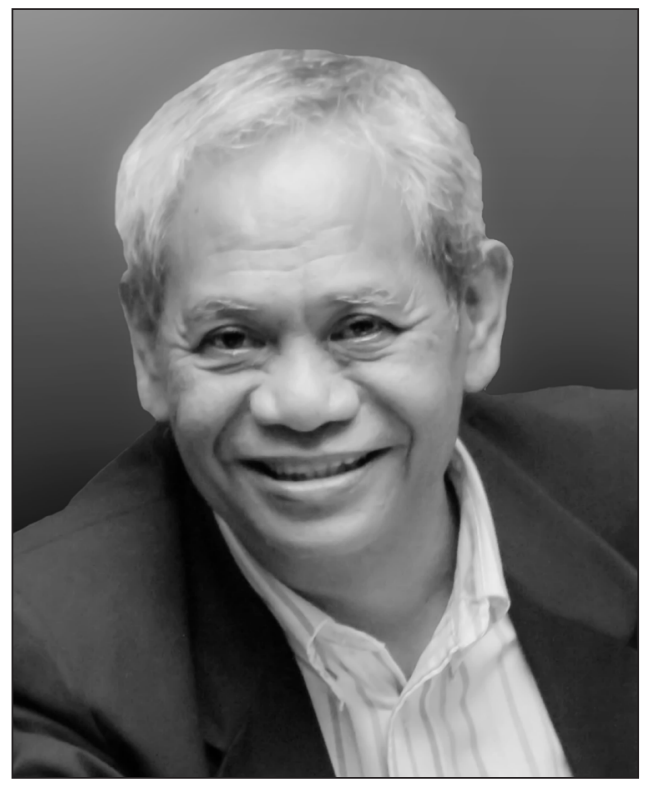

Carlos F. Dumlao, 'Caloy' as he is fondly called by friends, was born in Bayombong, Nueva Vizcaya on November 4, 1950. He studied in the Bayombong Central School for elementary, then to Nueva Vizcaya High School, graduating valedictorian from both schools. He took his B.S. Pre-Med from the University of the Philippines (U.P.) Diliman, finishing in 1970. He then entered the U.P. College of Medicine and graduated in 1975. He is a brod in the Mu Sigma Phi Fraternity where I got to know him. He was one-year senior and he would always have a helping hand to anyone in need. He looked fearsome because of his bulk and stance but deep inside he had a soft heart and was very humble, for a guy who happened to be a son of a governor.

Faith would have that we would be together again in the Department of Otolaryngology in the Philippine General Hospital. He was my immediate senior. He helped and taught me the rudiments of surgery. He was one of the "fastest guns alive" that he could finish a laryngectomy in an hour.

Because of the prodding of Dr. Mariano B. Caparas he took up the challenge of practicing in Baguio with the objective of establishing a training program there. The first few years were a challenge to him because he was not welcome there. The senior surgeons frowned on the fact that he performed head and neck surgery, particularly thyroidectomy. But he persisted and even befriended them. He succeeded in forming a Department of Otolaryngology - Head and Neck Surgery in Baguio General Hospital. He gave much of his time and talent to that department and has produced a good number of diplomates and fellows.

He was unpretentious. What you see is what you get. He was also a true friend and a dedicated family man. He was faithful to Josie, his wife and children Janie, Dessy, Biboy, Joboy and Popo.

One measure of success of a leader is the number of successors you have produced. He has done well in this. He has given much of himself to Baguio General Hospital, the Philippine Society of Otolaryngology - Head and Neck Surgery (PSO-HNS) Northern Luzon Chapter and to the PSO-HNS as a whole. His legacy will live on in his graduates in Baguio General Hospital and through his son Popo who just passed the Philippine Board of Otolaryngology - Head and Neck Surgery diplomate board examinations. Caloy, you have left your mark in Northern Luzon, particularly in Baguio City. May you rest in peace in God's bosom. 